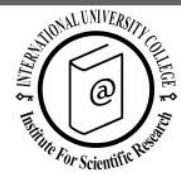

\title{
Attitudes towards Disintermediation in Hotel Reservations: Spanish Travellers' Profile
}

\author{
Giacomo Del Chiappa $^{1 *}$, Carlota Lorenzo-Romero ${ }^{2}$ and Martina G. Gallarza ${ }^{3}$
}

Received: 05/09/2013 Accepted: 24/04/2014

\footnotetext{
1 Department of Economics and Business, University of Sassari \& CRENoS, Sardinia, Italy. Via Muroni, 25, 07100 Sassari, Italy. Phone: +39 07921 3006. Email: gdelchiappa@uniss.it

2 Department of Business Administration, University of Castilla-La Mancha, Albacete, Spain. Plaza de la Universidad, 1. 02071 Albacete, Spain. Phone: +34 967599200 Ext. 2310. E-mail: Carlota.Lorenzo@uclm.es

${ }^{3}$ Marketing Department, University of Valencia, Valencia, Spain Facultad de Economía. Avda. de los Naranjos s/n, 46022 Valencia, Spain. Phone: +34 9638283 80. E-mail: martina.gallarza@uv.es

* Corresponding author
}

\begin{abstract}
This paper investigates the attitudes of different groups of travellers for and against the disintermediation of travel agencies. In the travel and tourism sector, the way in which people plan, buy and consume tourism products has been deeply transformed by the Internet and usergenerated content (UGC), thus challenging the role of traditional travel agencies. A web-based survey was carried out among Spanish consumers whose last hotel reservation was made through the Internet. A convenience sample of 986 complete questionnaires was obtained. Multivariate tests were used first to analyse the relationship and dependency between socio-demographic variables and second to look for significant differences between occasional, moderate and frequent buyers regarding their positive and negative perceptions of hotel reservations' disintermediation process. The findings reveal that significant differences exist between online buyers based on their sociodemographic characteristics and their online purchase experience, whereas they do not differ based on their likelihood of being influenced by UGC in their final choices. Another interesting finding is that the Internet is most frequently used for hotel reservations in short-term leisure and short-haul travel. Implications for travel agency managers are discussed and suggestions for further research are made.
\end{abstract}

(C) 2015 International University College. All rights reserved

Keywords: disintermediation; user-generated content; socio-demographic characteristics; hotel reservations; travellers; Spain.

Citation: Del Chiappa, G., Lorenzo-Romero, C. and Gallarza, M. (2015) Attitudes towards Disintermediation in Hotel Reservations: Spanish Travellers' Profile. European Journal of Tourism Research 9, pp. 129-143

\section{Introduction}

In recent years, as is widely known, the use of the Internet has increased dramatically, now accounting for 2.3 billion Internet users in the world with important penetration ratios in countries all over the world (Internet World 
Stats, 2011). The Internet has dramatically changed our behaviour as consumers, in the way in which we plan, buy and consume tourist products and services (Buhalis and Law, 2008). Among these changes, the most significant is in the area of user-generated content (UGC) and peer-to-peer applications, the so-called Web 2.0 (Musser and O'Reilly, 2006). These sources - UGC and Travel 2.0 applications are now the most relevant drivers of consumers' purchasing decisions (Gretzel and Yoo, 2008). In this sense, social media websites represent a significant share of the online tourism domain within the context of planning trips using a search engine, although the amount of social media displayed by Google may present variations (Xiang, 2011). As a consequence, it is pivotal for any tourism organization or tourism destination to run an effective social media policy as a way to increase the effectiveness of search engine optimization (SEO) strategies (Xiang and Gretzel, 2010), given the importance of the classification and position of results in influencing tourist choices (Díaz et al., 2012). Indeed, UGC is a key driver along with all the online searching and booking behaviour of tourists and, more precisely, UGC within thirdparties' websites. The so-called 'billboard effect" points out how consumers' decision making begins by looking at online travel agencies (Anderson, 2009, 2011; Del Chiappa, 2012), and this information - consisting of reviews and comments - clearly influences tourists' choices and online bookings (Del Chiappa, 2011a,b).

For all these reasons, it seems clear that the marketing strategies and practices of any tourism organization or tourism destination have to be rethought and reshaped, because of the gaining importance the Internet and social media are achieving (Stankov et al., 2010). In particular, the even higher number of consumers who use the Internet and UGC to search for information and to make their hotel reservations online has provoked a very sharp transformation of tourism intermediaries' role and activities (Kracht and Wang, 2010); the future of street travel agents has therefore become highly questionable. Specifically, the Internet has resulted in a gain of productivity and efficiency for hotels' sales tools: hospitality companies are now able to reach their customers directly and offer them any marketing promotions and sales (Tse, 2003; Law and Lau, 2005). UGC, in the meantime, is influencing tourist choices more than any information provided by travel agencies. As a result, recent research shows that UGC has even sometimes led to online buyers changing the accommodation already suggested by a travel agency (Del Chiappa, 2013a).

According to the Hospitality occupation survey carried out by the Instituto Nacional de Estadística [Spanish Statistic Institute] (2012a), the number of overnight stays in hotels during 2012 was close to 14 million, with more than 8.4 million foreign travellers $(63 \%$ of them preferring hotels for accommodation) and 5.5 million domestic travellers $(18 \%$ of them booking a hotel for their stay). Based on the Tourism movements survey of Spanish people - Familitur, a report elaborated by the Instituto de Estudios Turisticos [Spanish Tourism Studies Institute] (2012), the total expenditure on tourism amounted to more than EUR 31.2 million ( $0.7 \%$ more than the previous year). The outbound tourism generated by Spanish residents can be very valuable because of the relative importance of Spain in the ranking of European countries as tourism destinations. In fact, in 2012, Spain ranked in fifth position in the EU-27 measured by the number of nights spent abroad and seventh position in international tourism expenditure (Instituto de Estudios Turísticos [Touristic Studies Institute], 2012). According to the Instituto de Estudios Turísticos [Touristic Studies Institute] (2013), the number of departures in Spain was $12,200,000$ in 2012, thus confirming the importance of the Spanish tourism market.

According to the Instituto Nacional de Estadistica [Spanish Statistic Institute] (2012b), there were 10.5 million households with Internet access in 2012, thus resulting in $67.9 \%$ of Spanish households having Internet access as compared with $63.9 \%$ the year before. For $54.6 \%$ of online buyers, holiday accommodation was the product/service most often purchased online in 2012 in Spain, with other travel services accounting for $49.7 \%$, followed by tickets for entertainment with 40.3\% (Instituto Nacional de Estadística 
[Spanish Statistic Institute], 2012b). The balance between information gathering and service purchasing is close to $50 \%$ for the entire range of products (Territorio Creativo, 2011), with tourism leading all the sectors in Spain in terms of Internet penetration. Specifically, according to the Observatorio Nacional de las Telecomunicaciones y de la Sociedad de la Información [National Observatory of Telecommunications and of Information Society - ONTSI] (2011), 55.6\% of the total e-commerce income comes from air transportation, travel agencies, tour operators, hotels, camping and road transportation. According to eMarketer (2012a), travel websites reached $58.7 \%$ of Spanish Internet users, and according to eMarketer (2012b), social network users are expected to reach 21.2 million in 2014, a rise from 15.5 million in 2011. Amadeus (2011) reports that $71 \%$ of Spanish social media users make use of peerto-peer travel applications for travel-related purposes. According to the Instituto Nacional de Estadística (2012a), $76 \%$ of trips were made without booking, $4 \%$ fewer than the previous year, demonstrating the greater presence of customers booking trips with accommodation and transportation, with no involvement of travel agents. According to Pons (2012), 40\% of all travel bookings in Spain were made online in $2011,8 \%$ more than in 2010 . The aforementioned data and figures allow us to observe the importance of the Internet as a heavily growing channel used by Spanish travellers to book hotel accommodation, provoking a strong ongoing disintermediation process.

However, to the best of our knowledge, little research has been devoted to examining the online perceptions of hotel room buyers coming from different groups with different online purchasing experiences. Prior research (e.g. Цzturan and Roney, 2004; Law, 2009; Del Chiappa, 2011a,b, 2013a,b) has focused on specific geographical areas, but to our understanding, no comparative study has been interested in Spanish online buyers' perceptions either in favor of or against the disintermediation of hotel reservations. Similar research exists in the context of Italy, aimed at exploring occasional, moderate and frequent buyers' likelihood to change, based upon UGC, the accommodation already suggested by a travel agency (Del Chiappa, 2013a,b). The present study goal is to help fill this gap by conducting, presenting and discussing an empirical investigation with a sample of 986 online Spanish buyers.

The choice of Spain as the research site for this study is due to two reasons. First, Spain has not been spared on issues of disintermediation and re-intermediation. In this sense, in line with prior studies focusing on different geographical areas (e.g. Law, 2009; Del Chiappa, 2013a,b), our work can provide researchers with additional knowledge on the scientific debate about disintermediation, by exploring the extent to which differences based on cultural background may exist and should therefore be investigated via cross-cultural comparison. All this should be undertaken whilst also considering the relative power that UGC exerts on tourists' decision making, compared with information delivered by traditional travel agencies. Second, the study can provide practical knowledge and recommendations useful for hotel marketers, travel agencies and destination marketers interested in targeting the Spanish tourism demand.

\section{Background literature}

The Internet is radically changing consumers' patterns of behaviour regarding the way in which they plan, buy and consume tourism services (Buhalis and Law, 2008). Considering the Internet and consumer behaviour in tandem, the general import of the argument is that the Internet facilitates the search for information, along with a wider range of retailers to choose from (Kirkbridea and Soopramaniena, 2010).

In this sense, important changes have been reported in tourism distribution channels since information and communication technologies (ICTs), the Internet and UGC began to pervade both the industry and the market. It is argued that electronic word of mouth (e-WOM) is able to exert a great influence on tourist choices (Litvin et al., 2008) due to the fact that tourism products are intangible goods (Lewis and Chambers, 2000) and are characterized by emotional, economic and psychological 
involvement (Swarbrooke and Horner, 2007). A higher level of credibility and reliability is thus derived from UGC sources in comparison with market-provided information; consequently, they are more likely to affect and influence tourist choices (Gretzel and Yoo, 2008; Weiss et al., 2008; Akehurst, 2009). In such a context, UGC can also provoke a change in tourists' decisions, after obtaining further information online (eMarketer, 2007; Del Chiappa, $2011 a, b)$, causing a shift in the selection of accommodation suggested by a travel agency (Del Chiappa, 2013a). Indeed, there are many reasons why consumers use social media, represented by the different types of social, functional, hedonic and psychological benefits that they can obtain from using peer-to-peer applications (Parra-López et al., 2011).

It is true that ICTs in general, and the Internet in particular, generate benefits for both tourism suppliers and tourism consumers. On the supply side, both sources allow suppliers to reduce their distribution costs and gain higher revenues and a larger marketplace (Law et al., 2004). On the demand side, they produce several benefits, such as saving time and costs when searching for information, stimulating and expanding e-WOM, obtaining tailor-made products and enabling access, anytime and anywhere, to a wider choice of travel service providers (Buhalis and Licata, 2002; Anckar, 2003). Nevertheless, the use of the Internet also involves some associated costs, for the tourism industry and for the tourists. In fact, it can influence tourism companies negatively when creating online price transparency, which in turn increases price competition, with permanent online offers, which eventually can damage customer loyalty (Wen, 2009).

It has been noted that the Internet and ICTs are not responsible for a decrease in the number of intermediaries in the distribution channel, but they have provoked the existence of "an increasingly complex array of intermediaries" (Kracht and Wang, 2010:736). The tourism industry structure has been reshaped as a "complex global network", in which different stakeholders, on a regular basis and at various levels, "will continue to compete, cooperate, merge, form partnerships, and change relationships" (Kratch and Wang, 2010:736).
In such a context, tourism services possess several features that describe those products that are appropriate for Internet commerce. According to prior research (e.g. Chaffey et al., 2003), they can be considered as informationbased products, easily distributed through the Web, which can also very often offer a better deal in comparison with other distribution channels.

The tourism and marketing-related literature presents rationales both in favour of and against the disintermediation of tourism distribution channels. The so-called disintermediation debate has led to a discussion on both the revenue-generating aspects of tourism distribution and the information-searching stage in consumers' decision-making process (Grønflaten, 2011). The argumentation for and against disintermediation is varied. Merits can be related to the great flexibility and variety of consumer choice, faced with travel agency personnel with normally a poor level of training and competence, alongside a certain bias towards suppliers that offer overriding commissions. Among the arguments against disintermediation, the benefits from travel agencies are normally based on customers' time-saving procedures, the human touch provided in one-to-one interchanges and a reduction in uncertainty and insecurity ensured by assuming the responsibility for all the arrangements (Buhalis, 1998).

Kaewkitipong (2011) points out how, in practice, the process of disintermediation, despite becoming increasingly intense, does not necessarily mean the removal of travel agents from the tourism value chain; they are just required to acclimatize. In his review of both academic literature and practical survey research, this author shows that the impact of disintermediation on Thai travel agencies might not be as extreme as that suffered by European tourism ones. Such a study enhances the need to take a local look at disintermediation, as the present study does, in which cultural and geographical patterns might challenge and shape the overall balance between online and offline travel agencies.

Furthermore, Grønflaten (2011) underlines that 
the view on the topic of disintermediation must follow an information search perspective. Tourists can use the Internet to make their hotel bookings in various ways and can be divided, as researchers already know, into "lookers" and "bookers": the former are those who only wish to acquire information and the latter are those who also use the Internet to buy tourism services. Recent studies have revealed a proportion of $78 \%$ of "lookers", of whom $67 \%$ were also "bookers", and a very small number using travel agencies (Toh et al., 2011). In this sense, several sociodemographic and behavioural characteristics have been pointed out as the main differences between "lookers" and "bookers" (Morrison et al., 2001): the number of years they have been using the Internet, the number of weekly hours they surf the Internet, etc. There is also a higher propensity to purchase online related to age, education and level of income (Bonn et al., 1998; Weber and Roehl, 1999; Law et al., 2004). In this sense, younger groups were found to be less likely to prefer travel agents than senior groups when searching for information, and people older than 59 years, involved in an organized tour, showed a preference for a combination of travel agents and face-to-face contact (Grønflate, 2011). However, in other studies, younger people made significantly fewer online hotel bookings than their older counterparts (Law, 2009). Being more suspicious than others about the information available online, the "grey market" considers the Internet mainly for information searching (Graeupl, 2006). In fact, the attitude towards and beliefs about the channel affect online channel use differently: e-tail attributes indirectly impact on continued usage as mediated through beliefs about using the channel (Liu et al., 2011).

Based on the previous literature analysis, this study aims to answer the following questions:

- Do significant differences exist among online buyers, based on their sociodemographic characteristics and online purchase experience?

- How does UGC influence the online buyers' choices? Do consumers change the accommodation suggested by a travel agency based upon UGC?
- Do online buyers use the Internet for their hotel booking differently based on the type of travel?

- Do significant differences exist between online buyers, based on their views for and against the arguments of disintermediation?

\section{Methodology}

The present study, which was exploratory in nature, targeted exclusively adults resident in Spain and at least 18 years old. A structured questionnaire was developed based upon the previous literature on the perception of travellers of disintermediation in travel services (e.g. Buhalis, 1998; Law, 2009; Del Chiappa, 2013a,b).

The questionnaire was divided into three parts. First, as a start, we considered a qualifying question about whether interviewees had any previous experience of booking hotel rooms online. Therefore, only respondents who answered yes were selected. Some general demographic questions followed, in order to help define the sample profile. Second, using the format of a 5-point Likert scale ( $1=$ completely $\quad$ agree; $\quad 5=$ completely disagree), a list of 8 statements was proposed for respondents to assess their views as online buyers for and against the disintermediation of hotel reservations. Finally, the third part considered the types of travelling for which respondents usually make hotel reservations through the Internet, with a specific question on whether or not they have ever changed the hotel accommodation previously recommended by a travel agency after having read reviews and comments posted online.

Given the fact that our study targeted consumers who used online channels to make hotel reservations, the data collection was realized through an online questionnaire in the period October-November 2012. This also allowed us to take advantage of the lower costs and faster response times that an e-survey can guarantee over paper-and-pencil approaches (Lazar and Preece, 1999). Specifically, a snowball sampling technique was used (Wrenn et al., 2007). Through referral mechanisms, this technique provided us with an ever-expanding set of potential respondents (Goldenberg et al., 2009) in a very cheap and efficient way, thus 
representing the best choice to obtain a large sample of consumers who reside in different areas of Spain and to cope with the financial constraints we faced in managing the research project. However, it should be noted that as with most online surveys this study suffers from coverage error (Hwang and Fesenmaier, 2004). Further, as in all e-surveys, self-reported responses were provided on a voluntary basis, thus biasing the population towards those who

Table 1. Demographic profile of the respondents and $X^{2}$ analysis test

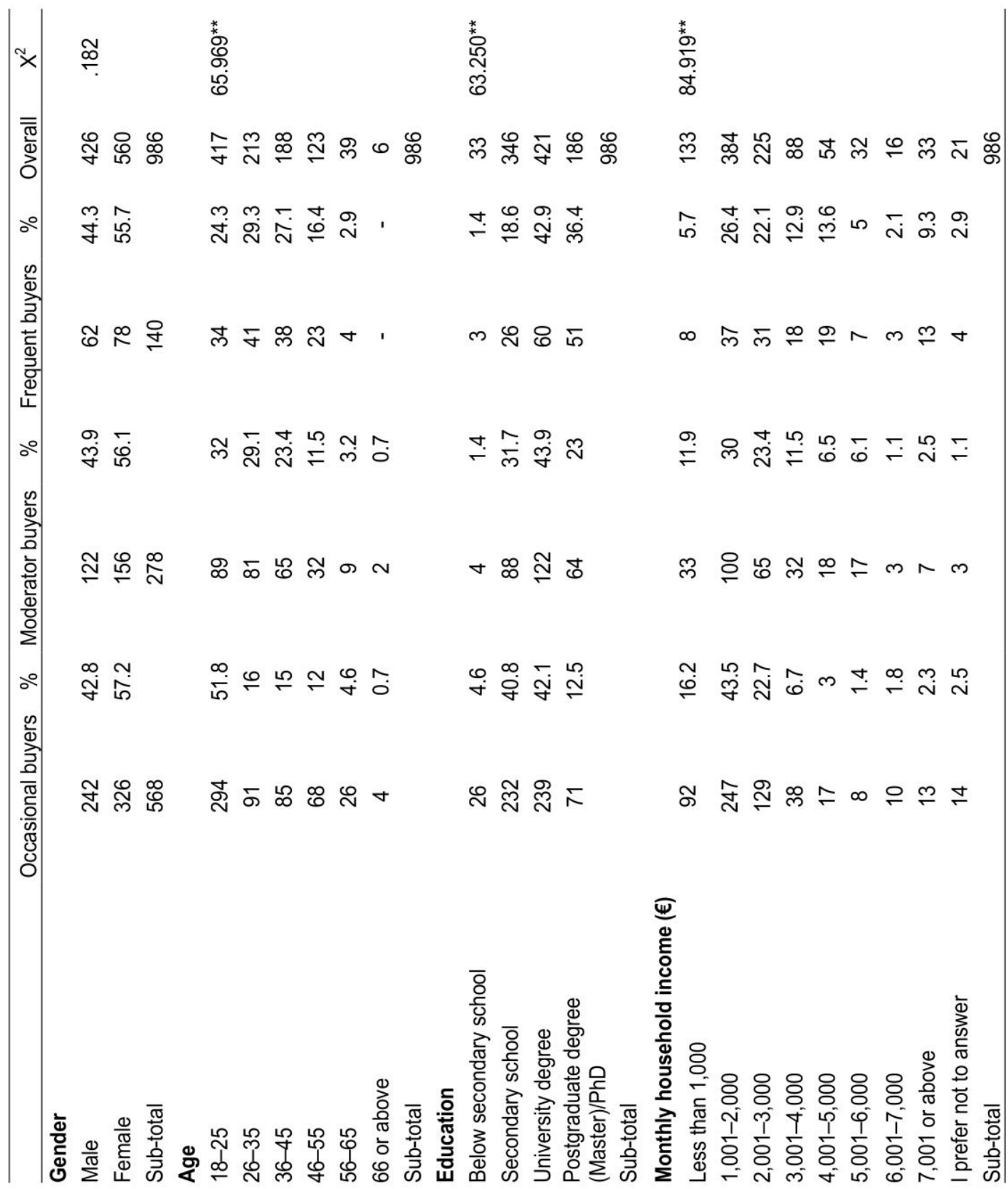

Note: * significant at the 0.05 level; ${ }^{* *}$ significant at the 0.01 level 
are more interested in the survey objects, that is, travel and hotel services (Li et al., 2008).

Initial subjects were generated from the list of 1,000 contacts owned by the research team. These 1,000 individuals, residing in different areas of Spain, received an e-mail inviting them to fill in the online questionnaire by clicking on a link provided in the e-mail. Further, they were invited to forward the survey to their contacts (over 18 years of age).

The data were coded and analysed using SPSS (version 17.0), and then descriptive analysis and cross-tabulations were extracted. With the aim of indicating the relationship/dependency between variables, and assessing whether significant differences exist between the ways in which occasional buyers, moderate buyers and frequent buyers assess their views for and against the disintermediation of hotel reservations, several statistical tests were considered: the chi-square test of significance, the independent t-test and the post-hoc analysis (Bonferroni test), according to the format questions.

\section{Results}

Following previous studies (e.g. Law, 2009; Del Chiappa, 2013a,b), in our work online buyers were regrouped into three categories: occasional buyers (those who have used the Internet to make bookings once or twice a year), moderate buyers (three to four times) and frequent buyers (more than four times). Table 1 shows the demographic characteristics of the participants in the survey.

The results from the $X^{2}$ analysis show significant differences among occasional, moderate and frequent buyers for age $\left[X^{2}=\right.$ $65.969, p<0.01]$, level of income $\left[X^{2}=84.919\right.$, $p<0.01]$ and education $\left[X^{2}=63.250, p<0.01\right]$. According to these findings, the younger respondents, those who are less educated and those with a lower income made significantly fewer online hotel room bookings than respondents who are older, more educated and have a higher income level (Table 1). These findings do not fully confirm the prior research carried out in other places such as China (Hong Kong) (e.g. Law, 2009) or Italy (e.g. Del Chiappa, 2013a,b). Specifically, the former study found significant differences only for age, while the latter did for age, gender, education and monthly household income.

As mentioned before, $\mathrm{X}^{2}$ analysis was also conducted to assess the level at which occasional, moderate and frequent buyers are

Table 2. Changes made to the accommodation suggested by a travel agency based upon UGC

\begin{tabular}{|c|c|c|c|c|c|c|c|c|c|}
\hline & \multicolumn{2}{|c|}{$\begin{array}{l}\text { Occasional } \\
\text { buyers }\end{array}$} & \multicolumn{2}{|c|}{$\begin{array}{l}\text { Moderate } \\
\text { buyers }\end{array}$} & \multicolumn{2}{|c|}{ Frequent buyers } & \multicolumn{2}{|c|}{ Total } & \multirow[t]{2}{*}{$x^{2}$} \\
\hline & $\mathrm{N}$ & $\%$ & $\mathrm{~N}$ & $\%$ & $\mathrm{~N}$ & $\%$ & $\mathrm{~N}$ & $\%$ & \\
\hline Yes & 313 & 55.1 & 161 & 57.9 & 91 & 65 & 565 & 100 & 4.631 \\
\hline No & $\begin{array}{l}255 \\
567\end{array}$ & 44.9 & $\begin{array}{l}117 \\
278\end{array}$ & 42,1 & $\begin{array}{l}49 \\
140\end{array}$ & 35 & $\begin{array}{l}421 \\
985\end{array}$ & 100 & \\
\hline
\end{tabular}

Note: * significant at the 0.05 level

Table 3. Internet use for reserving hotel rooms: analysis by type of travel (\%) (the respondents were allowed to give multiple answers)

\begin{tabular}{llllll}
\hline & Nationa & $\begin{array}{l}\text { Europea } \\
\mathrm{n}\end{array}$ & $\begin{array}{l}\text { Intercontinenta } \\
\mathrm{I}\end{array}$ & $\begin{array}{l}\text { Short-term } \\
\text { journeys } \\
\left(\begin{array}{l}4 \text { day } \\
\text { less) }\end{array}\right.\end{array}$ & $\begin{array}{l}\text { Medium-long-term } \\
\text { journeys } \\
\text { (5 days or more) }\end{array}$ \\
\hline Leisure & 93.8 & 73 & 35.1 & 80.6 & 68.3 \\
Business & 35.1 & 26.3 & 12.2 & 36.9 & 15 \\
Honeymoon & 23.3 & 13.8 & 10.5 & 20.7 & 15.7 \\
\hline
\end{tabular}


more likely to change the accommodation suggested by a travel agency, after having read UGC (Table 2). The findings reveal that frequent buyers change the accommodation $(65 \%)$ more than moderate buyers $(57.9 \%)$ and occasional buyers $(55.1 \%)$. However, contrary to the prior research (e.g. Del Chiappa, $2013 a, b)$, these results indicate that significant differences do not exist.

The respondents were also asked to give answers about the type of travel for which they used the Internet for reserving hotel rooms. According to Table 3, this happens the most for both short-haul (leisure: 93.8\%; business: $35.1 .9 \%$ ) and medium-haul (European) travel (leisure: 73\%; business: 26.3\%).

Similar results appeared for short-term journeys (leisure: $80.6 \%$; business: $36.9 \%$ ) and medium- to long-term leisure journeys (68.3\%). Moreover, when buying complex products, most people use traditional travel agencies (for instance honeymooners). Furthermore, regardless of the type of travel considered, business travellers use the Internet less frequently than leisure travellers. Finally, Table 4 shows Spanish online buyers' views in favour of or against the disintermediation of hotel reservations.

On the whole, the respondents showed disagreement with the statement that travel agents can provide a better service in terms of a human touch (mean $=2.92$, std $=1.220$ ). Consequently, they view travel agents as business-minded and prone to considering their financial incentives ahead of their customers' interests and needs (mean $=3.53$, std $=1.014$ ). Along the same line, Spanish online buyers disagree with the idea of coping, as consumers, with the cost of commission to travel agents for their hotel rooms (mean = 2.76 , std $=1.042$ ). At the same time, they do not share the advantage of seeking advice from travel agents, mainly preferring the Internet (mean $=2.23$, std $=1.209)$. Travel agencies were seen as being able to personalize the services to be delivered to consumers (mean = 3.51 , std $=.941$ ) but just slightly good in understanding the consumers' needs and desires and suggesting the best accommodation (mean $=3.33$, std $=.980$ ).
Moreover, the respondents consider websites as a more flexible channel for information searching and making reservations (mean = 3.86 , std $=1.020$ ), allowing consumers to perform most functions of hotel searching and room purchasing more conveniently (mean = 4.43 , std $=.814$ ). Furthermore, the respondents were reported as considering the Internet and UGC uploaded online as an important (mean = 3.87 , std $=1.015$ ) and trustworthy (mean = 3.59 , std $=.971$ ) source of information to be used when booking hotel rooms. Online buyers did prefer to use the Internet when making hotel reservations because this saves time (mean $=4.02$, std $=1.045)$ and money $($ mean $=$ 3.73 , std $=.997$ ) and allows them to increase their job productivity as they can access the service 24 hours a day (mean $=4.14$, std $=$ .990 ) without any kind of temporal constraints. Further, the respondents reported using the Internet to make hotel reservations as a way to have fun and enjoy their free time (mean = 3.48, std $=1.166$ ). Nevertheless, the respondents did slightly agree that travel agents offer risk reduction (mean $=3.26$, std $=$ 1.069 ) and professional counselling (mean $=$ 3.31 , std $=1.042$ ). To sum up, it could be said that the respondents were quite clearly in favour of disintermediation.

The results in Table 4 highlight significant differences in all but two questions between the opinions for and those against disintermediation expressed by occasional, moderate and frequent online buyers. In comparison with both the occasional and the moderate buyers, the frequent ones show a more positive view about the flexibility of websites $(F=4.205, p<0.05)$ alongside the chance to perform most hotel searching and room buying functions at their convenience $(F=$ 9.903, $p<0.01)$, thus saving time $(F=5.149$, $p$ $<0.01)$ and other costs $(F=3.726, p<0.05)$ and enhancing their job productivity $(F=5.149$, $p<0.01)$. Further, they have a more positive view about the idea of using the Internet to make hotel room reservations as a way to have fun and entertain themselves in their free time $(F=3.754, p<0.05)$. Moreover, frequent buyers consider UGC as a more important $(F=$ $3.874, p<0.05)$ and trustworthy $(F=4.407, p<$ 0.05 ) source of information to be used when making hotel room reservations than occasio- 
Table 4. A comparison between online buyers' views for and against disintermediation

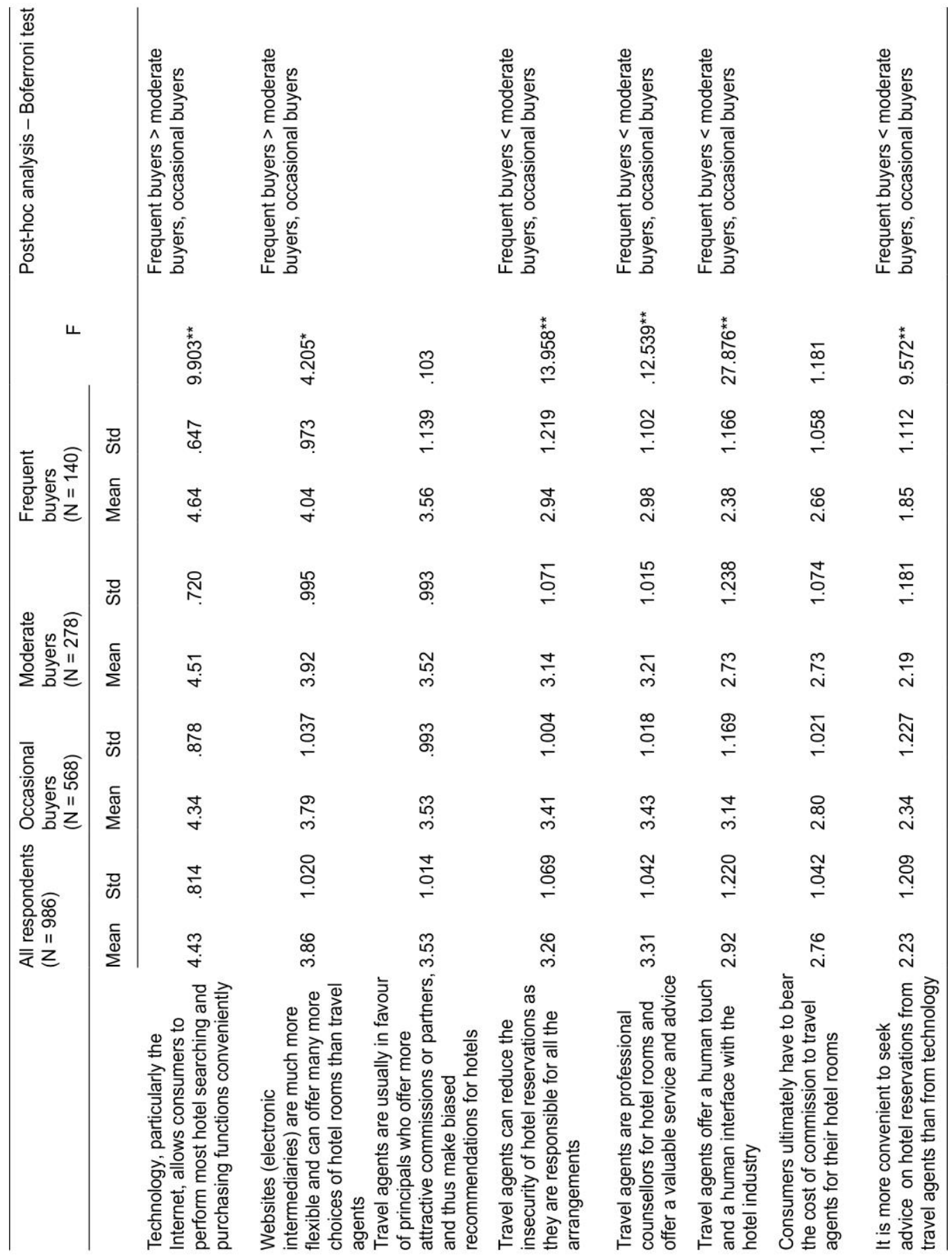

Note: * significant at the 0.05 level; ** significant at the 0.01 level 


\begin{tabular}{|c|c|c|c|c|c|c|c|c|c|}
\hline \multicolumn{2}{|c|}{ 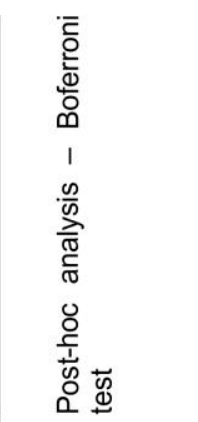 } & 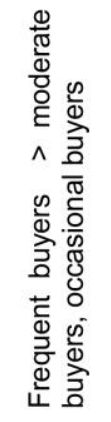 & 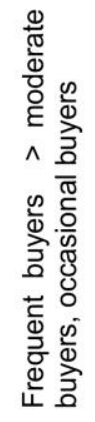 & 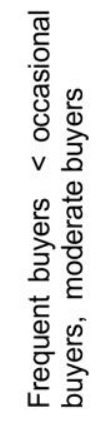 & 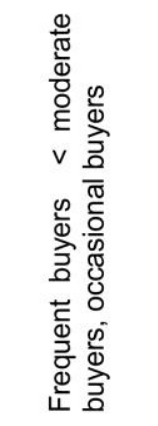 & 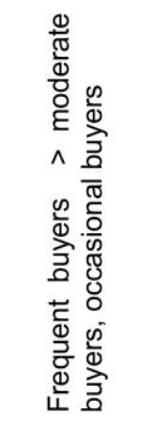 & 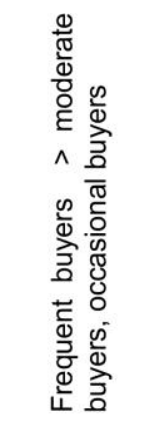 & 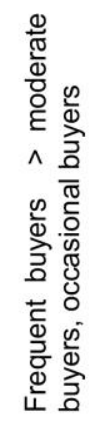 & 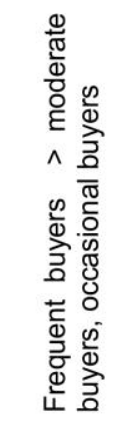 \\
\hline \multicolumn{2}{|c|}{ ५ } & $\begin{array}{l}\stackrel{*}{*} \\
\infty \\
\infty \\
\infty\end{array}$ & \begin{tabular}{l}
$\stackrel{*}{*}$ \\
\multirow{\sigma}{*}{} \\
$\stackrel{+}{*}$
\end{tabular} & $\begin{array}{l}\text { * } \\
8 \\
0 \\
0 \\
0\end{array}$ & $\begin{array}{l}\stackrel{*}{*} \\
\stackrel{0}{0} \\
\stackrel{+}{*}\end{array}$ & $\frac{\text { 旁 }}{\frac{5}{5}}$ & 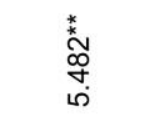 & 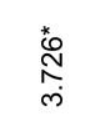 & $\begin{array}{l}\text { 范 } \\
\stackrel{\infty}{\infty}\end{array}$ \\
\hline \multirow{2}{*}{ 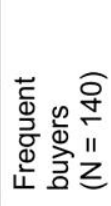 } & 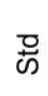 & 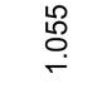 & 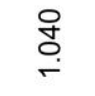 & 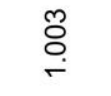 & $\begin{array}{l}0 \\
\stackrel{0}{0}\end{array}$ & $\underset{\leftarrow}{\bar{\varnothing}}$ & $\stackrel{\sim}{\stackrel{N}{r}}$ & 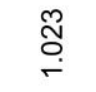 & $\stackrel{\stackrel{N}{N}}{\stackrel{N}{n}}$ \\
\hline & $\begin{array}{l}\text { 胥 } \\
\sum^{\infty}\end{array}$ & $\stackrel{\mathscr{H}}{\stackrel{\leftrightarrow}{+}}$ & $\begin{array}{l}\stackrel{\mathscr{L}}{\rho} \\
\stackrel{m}{n}\end{array}$ & $\underset{m}{m}$ & $\underset{\dot{m}}{\check{m}}$ & $\underset{+}{\stackrel{\sim}{+}}$ & $\begin{array}{l}\mathscr{m} \\
\dot{\sim}\end{array}$ & চ্ & $\underset{m}{\stackrel{N}{N}}$ \\
\hline \multirow{2}{*}{ 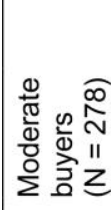 } & क & $\bar{\sigma}$ & స్. & స̆ & ڤ̂. & 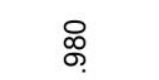 & 仓़. & ô. & $\underset{\stackrel{\overbrace{}}{\leftarrow}}{\stackrel{2}{*}}$ \\
\hline & $\begin{array}{l}\text { 䒜 } \\
\sum^{\mathbb{N}}\end{array}$ & ब్ల & $\begin{array}{l}\varrho \\
ٍ\end{array}$ & $\underset{j}{\stackrel{\Xi}{*}}$ & $\begin{array}{l}\text { m. } \\
\text { m. }\end{array}$ & $\stackrel{\circ}{\stackrel{ }{*}}$ & $\stackrel{\infty}{\underset{\sim}{*}}$ & $\underset{j}{\Gamma}$ & $\underset{\text { f }}{\tilde{j}}$ \\
\hline \multirow{5}{*}{ 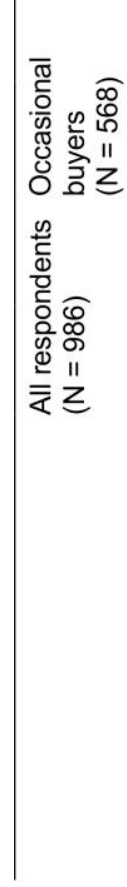 } & 总 & $\stackrel{\infty}{\underset{\leftarrow}{+}}$ & ลิ & চs & 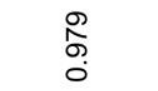 & $\underset{\stackrel{\leftrightarrow}{\leftrightarrow}}{\stackrel{+}{r}}$ & 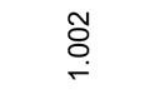 & ஜூ & 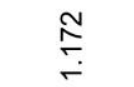 \\
\hline & $\begin{array}{l}\text { ॠ్ } \\
\sum^{\mathbb{N}}\end{array}$ & 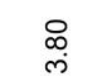 & స్ల్ల & 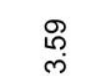 & $\stackrel{\infty}{\infty}$ & 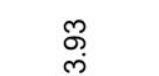 & $\underset{\forall}{\stackrel{0}{*}}$ & : & $\stackrel{\sim}{\text { ॄ }}$ \\
\hline & के & $\stackrel{\text { }}{\circ}$ & $\tilde{\sigma}$ & $\bar{\sigma}$ & @ & $\stackrel{\substack{0 \\
\hdashline}}{ }$ & প্. & Sิ & 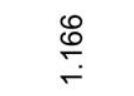 \\
\hline & 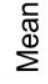 & & 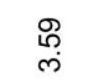 & in & $\underset{m}{m}$ & 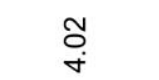 & $\underset{\forall}{\stackrel{J}{*}}$ & 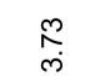 & 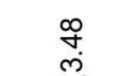 \\
\hline & & 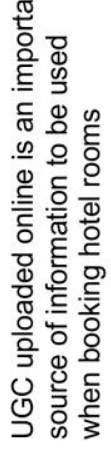 & 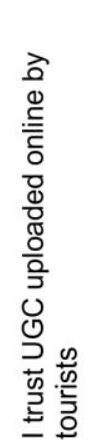 & 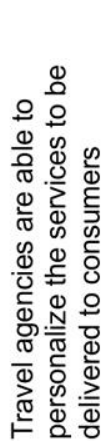 & 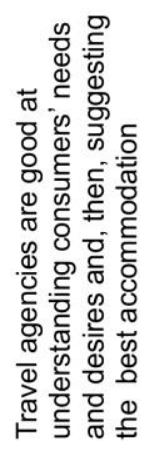 & 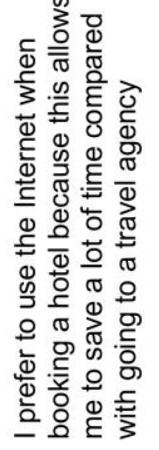 & 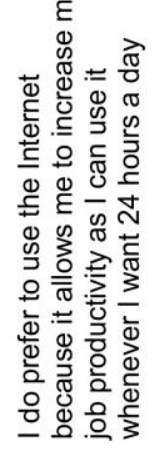 & 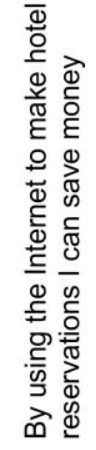 & 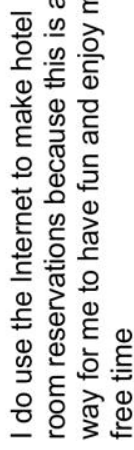 \\
\hline
\end{tabular}


nal and moderate buyers. On the contrary, a less positive view of the service provided by travel agents was found among frequent buyers in comparison with moderate or occasional buyers in six of the eight questions: risk reduction $(F=13.598, p<0.01)$, service provided with a human touch $(\mathrm{F}=27.876, \mathrm{p}<$ $0.01)$ and professional advice ( $F=12.539, p<$ 0.01 ), being able to understand the consumers' needs fully $(F=4.365, p<0.05)$ and being able to personalize the services delivered to them ( $F$ $=5.697, \mathrm{p}<0.01$ ). Further, frequent buyers show a less positive opinion regarding the convenience of seeking advice from traditional travel agents $(F=9.572, p<0.01)$. As a whole, it can be said that our findings report that frequent buyers are more positive towards Internet-based hotel reservations than moderate or occasional buyers, confirming prior research on different perceptions of online buyers for and against the topic of disintermediation (e.g. Law, 2009; Del Chiappa, 2013a,b).

\section{Conclusion}

The aim of this study was to explore the views of Spanish online buyers for and against the disintermediation of hotel reservations.

Differently from prior research (e.g. Law, 2009; Del Chiappa 2013a,b), our findings demonstrate that occasional, moderate and frequent buyers show significant differences based on their age, level of income and level of education, thus confirming a higher propensity to purchase online related to these three sociodemographic traits (e.g. Bonn et al., 1998). The findings also confirm that the type of travel has an effect on online buyers' likelihood of making hotel room reservations through the Internet. Specifically, the trend shown is the following: the Internet is preferred for convenience goods and low-involvement products (Chu, 2001), while traditional channels (travel agents) are preferred when purchasing complex products (Wertener and Klein, 1999) and by business travellers (Cobanoglu, 2001). Our results do not fully confirm the previous studies carried out among Italian travellers in which significant differences were found in the way in which moderate, occasional and frequent buyers change the accommodation that has been suggested by a travel agent after having read
UGC (Del Chiappa, 2013a,b). This discrepancy in the results suggests the need for further research on the topic via cross-cultural comparison. Finally, the results reveal that moderate and occasional buyers hold more negative views towards Internet-based hotel reservations than frequent buyers.

These findings provide valuable knowledge for both researchers and hospitality managers. First, they provide interesting insights into the scientific debate on the topic of disintermediation as differences based on consumers' cultural background do exist and should thus be further investigated via crosscultural comparison. Second, the present study offers suggestions to both hotel marketers and traditional travel agencies. Hospitality marketers should design their websites to be more attractive to Spanish middle-aged people and those with a higher income who travel often and are heavy users of the Internet as a tool for both searching and booking hotels. Accordingly, the focus for hotel marketers should be not only on direct sales, but also on brand reputation, which should be monitored as it is projected in consumers' reviews and comments posted online. Specifically, hotel managers should "listen" constantly to the comments and reviews that tourists upload online and should participate and respond to them, thus increasing their e-brand reputation and the consumers' perception of functional utility (Parra-López et al., 2011). In the case of travel agents, this study recommends that they should obtain, create and maintain a presence in the electronic marketplace. Indeed, according to prior research (e.g. Tsai et al., 2005), travel agencies can recover their competitiveness by setting up their own corporate website and using the Internet as a collaborative tool to work with consumers, suppliers and partners and co-create better value. In this sense, the further step that travel agencies should take is to move away from being just booking offices and transform themselves into real travel consultants, in order to be more competitive (Anckar, 2003). Obviously, travel agencies will continue to exert a relevant role in the tourism distribution chain, at least for certain target segments and specific types of products (Law and Lau, 2005). Towards their already-existing clients, 
traditional travel agencies should concentrate their efforts on increasing the attitude of the targeted travellers, building and constantly enhancing their online and offline reputation and bringing innovation into their products and services (Del Chiappa, 2013a,b). According to our results, all these statements and recommendations are of interest for tourism organizations targeting Spanish consumers.

Aside from the theoretical and managerial contribution of the study, there are some limitations that ought to be mentioned. As with most online surveys, this study suffers from the coverage error given. As a consequence, the sample cannot be considered representative of Spanish online buyers, even though its size is significant. Secondly, generalization of our findings is difficult because of the particular method of sampling used (i.e., snowball sampling). Finally, the dimension of perceived risk and security was not explicitly and deeply investigated in this research even though it was recognized as a relevant moderating factor influencing the way in which consumers use the Internet (Chen, 2011). This factor should be deeply investigated if this study is replicated. In the future, it would be necessary to include such a dimension and interesting to verify whether and how Spanish travel agencies currently use the Internet and social media in their marketing strategy. In line with the literature reviewed (Grønflaten, 2011), the issue of disintermediation in Spain could also be studied by adopting an information search perspective, from which different consideration is made of information sources and information channels. All these questions are future knowledge to be gained on the subject of disintermediation, which will obviously provide further insights for both tourism-related professionals and scholars.

\section{Acknowledgment}

The authors are grateful to the anonymous reviewers for their valuable feedback and suggestions which have greatly enhanced the quality of this manuscript

\section{References}

Akehurst, G. (2009). User generated content: The use of blogs for tourism organizations and tourism consumers. Service Business, 3 (1), 51-61.

Amadeus (2011). The always-connected traveller: How mobile will transform the future of air travel. URL: http://www.amadeus.com/airlineit/thealways-connectedtraveller/docs/amadeus-the-alwaysconnected-traveller-2011-en.pdf (Accessed on 17.07.2013).

Anckar, B. (2003). Consumer intentions in terms of electronic travel distribution: Implications for future market structures. e-Service Journal, 2, 68-86.

Anderson, C. K. (2009). The billboard effect: Online travel agent impact on non-OTA reservation volume. CHR Report. The Center for Hospitality Research at Cornell University, 9 (16).

Anderson, C. K. (2011). Search, OTAs, and online booking: An expanded analysis of the billboard effect. CHR Report. The Center for Hospitality Research at Cornell University, 11 (8).

Bonn, M. A., Furr, L. H. \& Susskind, A. M. (1998). Using the Internet as a pleasure travel planning tool: An examination of the socio demographic and behavioral characteristics among Internet users and nonusers. Journal of Hospitality and Tourism Research, 22, 303-317.

Buhalis, D. (1998). Strategic use of information technologies in the tourism industry. Tourism Management, 19, 409-421.

Buhalis, D. \& Law, L. (2008). Progress in information technology and tourism management: 20 years on and 10 years after the Internet - The state of etourism research. Tourism Management, 29, 609-623.

Buhalis, D. \& Licata, M. C. (2002). The future eTourism intermediaries. Tourism Management, 23, 207-220.

Chaffey, D., Mayer, R. Johnston, K. \& EllisChadwick, F. (2003.) Internet marketing, second edition. Englewood Cliffs, New York: Prentice Hall.

Chen, S. L. (2001). Effects of value, affect, security, and web content on informational and transactional usage of the Internet. Asia Pacific Journal of Tourism Research, 6 (81), 63-72. 
Del Chiappa, G., Lorenzo-Romero, C. and Gallarza, M. (2015) / European Journal of Tourism Research 9, pp. 129-143

Chu, R. (2001). What online Hong Kong travelers look for on airline/travel website? International Journal of Hospitality Management 20, (1), 95100.

Cobanoglu, C. (2001). Analysis of business travelers' hotel selection and satisfaction. $\mathrm{PhD}$ Thesis, Oklahoma State University, USA.

Del Chiappa, G. (2011a). Trustworthiness of travel 2.0 applications and their influence on tourist behaviour: An empirical investigation in Italy. In Law, R., M. Fuchs, F. Ricci (ed.) Information and communication technologies in tourism 2011. Vienna, Austria: Springer, 343-353.

Del Chiappa, G. (2011b). Disintermediation of hotel reservations: The perception of different groups of Italian online buyers. TTRA Europe and AFM Conference, Archamps, France.

Del Chiappa, G. (2012). User generated content and its influence on tourists' choices: How do tourists make hotel reservations online? Turistica, Special Issue "Content Personalization and Multimedia Marketing for Destinations and Tourism Business", 1, 39-50.

Del Chiappa, G. (2013a). Internet versus travel agencies: The perception of different groups of Italian online buyers. Journal of Vacation Marketing, 19, 1-12.

Del Chiappa, G. (2013b). Italian online buyers' perceptions of the topic of disintermediation and user generated content. In Kozak, M., N. Kozak (ed.) Aspects of tourist behavior. Newcastle, United Kingdom: Cambridge Scholars Publishing.

Díaz, E., Blázquez, J. J. \& Martín-Consuegra, D. (2012). European tourist destinations on the Internet search engines. European Journal of Tourism Research, 5 (2), 171-175.

eMarketer (2007). Niche sites invigorate online travel. URL: http://www.eMarketer.com (Accessed on 11.04.2013).

eMarketer (2012a). Online travel trends in Germany vary by age: Travel is a top ecommerce activity for Internet users over $50 . \quad$ URL: http://www.emarketer.com/Article/Onlin
e-Travel-Trends-Germany-Vary-byAge/1009430\#h7RE05ocklJuJmDC.99 (Accessed on 17.07.2013).

eMarketer (2012b). Where in the world are the hottest social networking countries? URL:

http://www.emarketer.com/Article/Wher e-World-Hottest-Social-Networking-

Countries/1008870 (Accessed on 17.07.2013).

Goldenberg, J., Han, S. Lehmann, D. \& Hong J. (2009). The role of hubs in the adoption processes. Journal of Marketing, 73 (2), 1-13.

Graeupl, A. (2006). Silver surfers and their online information search behaviour. In Hitz, M., M. Sigala, J. Murphy (ed.) Information and communication technologies in tourism 2006 : Proceedings of the international conference. Lausanne, Switzerland: Springer-Verlag.

Gretzel, U. \& Yoo, K. H. (2008). Use and impact of online travel reviews. In O'Connor, P., W. Höpken, U. Gretzel (ed.) Information and communication technologies in tourism 2008. Vienna, Austria: Springer, 35-46.

Grønflaten, Ø. (2011). Predicting travelers' choice of information sources and information channels. Journal of Travel Research 48, 230-244.

Hwang, Y. H. \& Fesenmaier, D. R. (2004). Coverage error embedded in selfselected Internet-based samples: A case study of Northern Indiana. Journal of Travel Research, 42 (3), 297-304.

Instituto de Estudios Turísticos [Touristic Studies Institute] (2012). España en Europa. El comportamiento de los residentes en la Unión Europea [Spain in Europe. Behaviour of Spanish residents in the Union Europe]. URL: http://www.iet.tourspain.es/es-

ES/estadisticas/analisisturistico/espana eneuropa/anuales/Espa\%C3\%B1a\%20 en\%20Europa\%202011.pdf (Accessed 12.14.2013)

Instituto de Estudios Turísticos [Touristic Studies Institute] (2013). Encuesta de movimientos turísticos de los españoles 2012, Familitur [Touristic movements of Spanish tourists survey 
2012, Familitur]. URL:

http://www.iet.tourspain.es/es-

ES/estadisticas/familitur/Anuales/Infor

me\%20anual\%20de\%20Familitur.\%20

A\%C3\%B10\%202012.pdf (Accessed

12.14.2013).

Instituto Nacional de Estadística [Spanish Statistic Institute] (2012a). Encuesta de ocupación hotelera [Hospitality occupation survey]. URL: http://www.ine.es/jaxi/menu.do?type $=p$ caxis\&path $=\% 2 \mathrm{Ft} 11 \% 2 \mathrm{Fe} 162 \mathrm{eoh} \& \mathrm{file}=$ inebase (Accessed 02.04.2013).

Instituto Nacional de Estadística [Spanish Statistic Institute] (2012b). Survey on equipment and use of information and communication technologies (ICT) in households year 2012. URL: http://www.ine.es/en/prensa/np738_en. pdf (Accessed 17.07.2012).

Internet Word Stats (2011). Top 20 countries with the highest number of Internet users.

URL: http://www.Internetworldstats.com/top2 0.htm (Accessed 31.08. 2011).

Kaewkitipong, L. (2011). Disintermediation in the tourism industry: An investigation of Thai tourism SMEs. International Journal of Electronic Business, 9, 516535.

Kirkbridea, C. \& Soopramaniena, D. (2010). Competition online and the preference ordering of offers. International Review of Retail, Distribution and Consumer Research, Special Issue: "Evaluating the Role of Electronic Commerce in Transforming the Retail Sector", 20, 379-395.

Kracht, J. \& Wang, Y. (2010). Examining the tourism distribution channel: Evolution and transformation. International Journal of Contemporary Hospitality Management, 22 (5), 736-757.

Law, R. (2009). Disintermediation of hotel reservations: The perception of different groups of online buyers in Hong Kong. International Journal of Contemporary Management, 21, 766-772. Hospitality

Law, R., Leung, K. \& Wong J. (2004). The impact of the Internet on travel agencies. International Journal of
Contemporary

Management, 16, 100-107.

Hospitality

Law, R. \& Lau, W. (2005). A study of the perceptions of Hong Kong hotel managers on the potential disintermediation of travel agencies. Journal of Travel and Tourism Marketing, 17, 117-131.

Lazar, J. \& Preece, J. (1999). Designing and implementing Web-based surveys. Journal of Computer Information Systems, 39 (4), 63-67.

Lewis, R. C. \& Chambers, R. E. (2000). Marketing leadership in hospitality, foundations and practices. New York: Wiley.

Li, X., Cheng, C. K., Kim, H. \& Petrick, J. F. (2008). A systematic comparison of first-time and repeat visitors via a twophase online survey. Tourism Management, 29 (2), 278-293.

Litvin, S. W., Goldsmith, R. E. \& Pan, B. (2008). Electronic word-of-mouth in hospitality and tourism management. Tourism Management, 29 (3), 458-468.

Liu, C., Forsythe, S. \& Black, W. C. (2011). Beyond adoption: Sustaining online shopping. International Review of Retail, Distribution and Consumer Research, 21, 71-93.

Morrison, A., Jing, A. O'Leary, J. \& Cai, L. (2001). Predicting usage of the Internet for travel bookings: An exploratory study. Information Technology and Tourism, 4, 15-30.

Musser, J. \& O'Reilly T. (2006). Web 2.0 principles and best practices. O'Really Radar Report. URL: http://radar.oreilly.com/ (Accessed 20.09.2012).

Observatorio Nacional de las Telecomunicaciones y de la Sociedad de la Información [National Observatory of Telecommunications and of Information Society - ONTSI] (2011) Estudio sobre Comercio Electrónico B2C 2011 Edición 2012. URL:http://www.ontsi.red.es/ontsi/es/es tudios-informes/estudio-b2c-2011edición-2012 (Accessed 12.01.2013).

Özturan, M. \& Roney, S. A. (2004). Internet use among travel agencies in Turkey: An 
Del Chiappa, G., Lorenzo-Romero, C. and Gallarza, M. (2015) / European Journal of Tourism Research 9, pp. 129-143

exploratory study. Tourism Management, 25, 259-266.

Parra-López, E., Bulchand-Gidumal, J., Gutiérrez-Taño, D. \& Díaz-Armas, R. (2011). Intentions to use social media in organizing and taking vacation trips. Computers in Human Behavior 27, 640-654.

Pons, T. (2012) ¿Deberían los hoteleros españoles mejorar sus herramientas de distribución directa y comunicación para evitar la pérdida de beneficios? [Should Spanish hotels improve their direct distribution tools and communication to prevent the loss of benefits?]. XXVI AEDEM Conference, Barcelona, Spain. URL: http://www.slideshare.net/tomeupons/di stribucin-hotelera-motor-de-reservashotel-resultados-pp-aedem2012-3 (Accessed 20.10.2012).

Stankov, U., Lazić, L. \& Dragićević, V. (2010). The extent of use of basic Facebook user-generated content by the national tourism organization in Europe. European Journal of Tourism Research, 3 (2), 105-113.

Swarbrooke, J., \& S. Horner (2007). Consumer behaviour in tourism. The Netherlands: Elsevier Ltd.

Territorio Creativo, S. L. (2011) Social Commerce 2011 - Situación y perspectivas [Social commerce 2011 Situation and perspectives]. URL: http://www.territoriocreativo.es/wpcontent/uploads/2011/10/informe_oct_2 011_resume115.pdf (Accessed 10.12.2012).

Toh, R. S., Raven, P. \& Dekay, F. (2011). Selling rooms: Hotel vs. third-party websites. Cornell Hospitality Quarterly, 52, 181-189.

Tsai, H., Huang, L. \& Lin, C. (2005). Emerging e-commerce development model for Taiwanese travel agencies. Tourism Management, 26 (5), 787-796.

Tse, A. C. (2003). Disintermediation of travel agents in the hotel industry. International Journal of Hospitality Management, 22, 453-460.

Weber, K. \& Roehl, W. S. (1999.) Profiling people searching for and purchasing travel products on the world wide web. Journal of Travel Research, 37, 291298.

Weiss, A. M., Lurie, N. H. \& Macinnis D. J. (2008). Listening to strangers: Whose responses are valuable, how valuable are they, and why? Journal of Marketing Research, 45 (4), 425-436.

Wen, I. (2009). Factors affecting the online travel buying decision: A review. International Journal of Contemporary Hospitality Management 21, 752-765.

Wertener, H. \& Klein, S. (1999). Information technology and tourism - A challenging relationship. Vienna: Springer-Verlag.

Wrenn, B., Stevens, R. E. \& Loudon D. L. (2007). Marketing research. Text and cases. New York: Haworth Press.

Xiang, Z. (2011). Dynamic social media in online travel information search: A preliminary analysis. In Law, L., M. Fuchs, F. Ricci (ed.) Information and communication technologies in tourism 2011. Vienna, Austria: Springer.

Xiang, Z. \& Gretzel, U. (2010). Role of social media in online travel information search. Tourism Management, 31 (2), 179-188. 